Rheumatic \&

Musculoskeletal Diseases

To cite: Guillaume-Czitrom S, Sibilia J, Nordal E. Growing up with chronic arthritis: the confusing matter of classification. RMD Open 2017;3:e000417. doi:10.1136/rmdopen-2016000417

- Prepublication history for this paper is available online. To view these files please visit the journal online (http://dx.doi.org/10.1136/ rmdopen-2016-000417)

Received 30 November 2016 Revised 13 February 2017 Accepted 1 March 2017

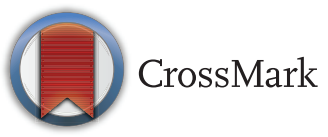

${ }^{1}$ Department of Adolescent Medicine, University Hospital of Bicêtre, APHP, Le KremlinBicêtre, France

2Department of Rheumatology, Hautepierre University Hospital, Strasbourg, France ${ }^{3}$ Department of Pediatrics, UIT The Arctic University of Norway and University Hospital of North Norway, Tromsø, Norway

Correspondence to Ellen Nordal;

ellen.nordal@icloud.com

\title{
Growing up with chronic arthritis: the confusing matter of classification
}

\author{
Séverine Guillaume-Czitrom, ${ }^{1}$ Jean Sibilia, ${ }^{2}$ Ellen Nordal ${ }^{3}$
}

Disease classification in rheumatology is a matter of debate, in paediatrics between International League Against Rheumatism (ILAR) classification 'pros and cons', as well as between paediatric and adult rheumatologists. Indeed, there is no consensus yet about how we should name the disease of adults with juvenile idiopathic arthritis (JIA) in childhood. The non-concordance of adult and paediatric classifications for chronic inflammatory rheumatic diseases is confusing for caregivers, and above all for our patients. Will they be 'lost in transition', as phrased by McDonagh and Viner, ${ }^{1}$ when their disease stays the same, but gets a new name? Will their treatment be modified according to this new name and the corresponding recommendations for adult disease management? Yes, it is definitely time to think about a thorough modification of the ILAR categories of childhood chronic arthritis. ${ }^{2}$

The ILAR agreed on a classification that comprises all types of idiopathic arthritis in children under the umbrella term of JIA, subdivided into seven categories comprising the systemic, oligoarticular, rheumatoid factor (RF)-negative polyarticular, RF-positive polyarticular, juvenile psoriatic arthritis (jPsA), enthesitis-related arthritis (ERA) and the undifferentiated form. ${ }^{3}$ This was the first time that Europeans and Americans agreed to speak the same language. However, since launched, the ILAR classification has been regularly criticised. $^{4-6}$ It was revised in 2001, and the reduced emphasis on heredity resulted in a significant decrease in the rates of children with undifferentiated arthritis. ${ }^{7}$ Calls for further modifications are nevertheless still numerous.

Martini $^{8}$ recognised that dividing patients into groups according to the number of joints involved at disease onset (oligoarticular/polyarticular JIA) was not gathering homogeneous categories; others claimed that strict exclusion criteria of the present classification excluded many authentic juvenile spondyloarthritides from the ERA category, ${ }^{9}{ }^{10}$ the same for the
jPsA category, ${ }^{11}{ }^{12}$ and even the RF-positive polyarticular category. ${ }^{13}$ The undifferentiated arthritis group varies markedly in frequency in different reports, because it depends on thorough work-up on heredity and other exclusion criteria. ${ }^{14}$ Contrary to the intentions of the ILAR, the undifferentiated group in follow-up tends to increase instead of decrease over time. ${ }^{15}$

A new proposal is emerging from Martini and colleagues to define a group composed of young children $\leq 6$ years of age with arthritis and presence of antinuclear antibodies (ANA). Indeed, two important papers from their team showed that the clinical characteristics of ANA-positive young children during the first 2 years after disease onset were very similar despite being classified into different ILAR categories, that is, RF-negative polyarticular, oligoarticular (persistent and extended), jPsA and undifferentiated arthritis, proving at the same time how heterogeneous these categories are. ${ }^{16}$ However, there are several concerns.

First, we have pointed out that the ANA immunofluorescence test is operatordependent and still not consensual in terms of threshold of positivity in different laboratories worldwide, even though the aforementioned studies define ANA positivity as two positive immunofluorescence tests at a titre of $\geq 1 / 160$ on Human Epithelial type 2 (HEp-2) cells at least 3 months apart. ${ }^{16} 17$ Second, ANA in JIA still have no identified biological target, and therefore no clear link to aetiology, pathophysiology or treatment option. ${ }^{18}$ Most importantly, prospective long-term follow-up of young children with ANA-positive JIA from different cohorts and geographical regions is still lacking. Therefore, ANA should not in our opinion be a classification determinant until more standardisation and evidence for relevance in treatment, disease course or outcome is available.

The clinical entity of psoriatic arthritis (PsA) versus enthesitis and spondyloarthritis 
$(\mathrm{SpA})$ in children is mutually exclusive in the ILAR classification, jPsA being restrictive compared with the classification of psoriatic arthritis (CASPAR) criteria. Recent findings of histologically inflamed entheses in dactylitic fingers, suggests that dactylitis and peripheral arthritic involvement often seen in young girls and enthesitis and axial involvement in older boys may be different manifestations of the same disease process. ${ }^{19}$ New knowledge has emerged on the role of certain interleukins, and subsequent targeted therapies are developed for PsA in adults. ${ }^{20}$ Too strict exclusion criteria for jPsA and ERA may exclude some children and adolescents from access to these treatments, and should therefore be reconsidered in a new ILAR classification.

In the September issue 2016 of RMD Open, an elegant article on rheumatic disease classification is presented by Oliveira-Ramos et $a l^{14}$ from Portugal. These authors describe the classification outcome of 426 patients with JIA followed for a mean of 22.5 years into adulthood and reclassified according to the adult classification criteria of chronic inflammatory rheumatic diseases (2010 American College of Rheumatology (ACR)/ European League Against Rheumatism (EULAR) for rheumatoid arthritis (RA), 1984 modified New York criteria for ankylosing spondylitis, CASPAR criteria for PsA, adult Still's disease, unclassifiable patients (undifferentiated arthritis)). The table is drawn from their data (table 1).

The left part of the table confirms what many paediatric rheumatologists believe: the systemic, the RF-positive polyarticular JIA, the ERA and the jPsA categories have their adult counterpart. Then, do we need different words to name them? ${ }^{2}$ Although the classifications of adult RA, PsA and SpA also include heterogeneous phenotypes, their treatment strategies are rapidly evolving, and the therapies constantly evaluated. Harmonising the name and the criteria of the disease for the systemic, the RF-positive polyarticular JIA, ERA and jPsA categories between childhood and adult units of care, may allow smoother transfer, and importantly, that they receive the targeted treatments at the right time.

In the right part of the table, the evolution of the RF-negative polyarticular and the oligoarticular groups are shown. Around $15 \%$ of the patients classified to have oligoarthritis (persistent and extended) fit SpA classification; almost $40 \%$ of the oligoextended and $60 \%$ of the RF-negative polyarticular categories fit the criteria for RA, and 24-60\% of the oligoarticular categories and RF-negative polyarticular are classified as undifferentiated chronic inflammatory arthritis. Of course, information on ANA status, and detailed clinical presentation at onset in relation to specific outcome categories (RA/ $\mathrm{SpA} / \mathrm{PsA} /$ undifferentiated) would be particularly interesting to look at.

Modification of the JIA classification should be based on knowledge from prospective cohorts and ongoing international registries extending far beyond 10 years follow-up in order to assess adult outcome. In addition, research on genetics and novel disease biomarkers will
Table 1 Paediatric JIA categories reclassified according to the adult classification criteria of chronic inflammatory rheumatic diseases in individuals with long-term follow-up

\begin{tabular}{|c|c|c|c|}
\hline \multicolumn{2}{|c|}{$\begin{array}{l}\text { Strong correlation between } \\
\text { paediatric/adult } \\
\text { classifications }\end{array}$} & \multicolumn{2}{|c|}{$\begin{array}{l}\text { Poor correlation between } \\
\text { paediatric/adult } \\
\text { classifications }\end{array}$} \\
\hline Onset (n) & $\begin{array}{l}\text { Long-term } \\
\text { follow-up (n) }\end{array}$ & Onset (n) & $\begin{array}{l}\text { Long-term } \\
\text { follow-up (n) }\end{array}$ \\
\hline $\begin{array}{l}\text { Syst JIA } \\
\text { (39) }\end{array}$ & $\begin{array}{l}\text { ASD (36) } 92.3 \% \\
\text { RA (2) } \\
\text { Undiff (1) }\end{array}$ & $\begin{array}{l}\text { RFneg } \\
\text { Poly JIA } \\
(63)\end{array}$ & $\begin{array}{l}\text { RA (36) } 57.1 \% \\
\text { AS (2) } \\
\text { USpA (2) } \\
\text { PsA (8) } \\
\text { Undiff(15) } \mathbf{2 3 . 8} \%\end{array}$ \\
\hline RFpos & RA (65) $95.6 \%$ & Persist & $\mathrm{RA}(4)$ \\
\hline $\begin{array}{l}\text { Poly JIA } \\
(68)\end{array}$ & $\begin{array}{l}\text { AS (1) } \\
\text { PsA (1) } \\
\text { Undiff (1) }\end{array}$ & $\begin{array}{l}\text { Oligo JIA } \\
(66)\end{array}$ & $\begin{array}{l}\text { AS (5) } \\
\text { USpA (9) } \mathbf{1 3 . 6 \%} \\
\text { EnterA (4) } \\
\text { PsA (5) } \\
\text { Undiff(39) } 59.1 \%\end{array}$ \\
\hline ERA (76) & $\begin{array}{l}\text { AS (41) } \\
\text { USpA (21) } \\
\mathbf{8 6 . 8 \%} \\
\text { EnterA (4) } \\
\text { PsA (6) } \\
\text { Undiff (4) }\end{array}$ & $\begin{array}{l}\text { Extend } \\
\text { Oligo JIA } \\
(54)\end{array}$ & $\begin{array}{l}\text { RA (21) } 38.9 \% \\
\text { AS (2) } \\
\text { USpA (10)18.5\% } \\
\text { EnterA (1) } \\
\text { PsA (1) } \\
\text { Undiff(19) } 35.2 \%\end{array}$ \\
\hline jPsA (13) & $\begin{array}{l}\text { PsA (12) } 92.3 \% \\
\text { USpA (1) }\end{array}$ & Undiff (6) & $\begin{array}{l}\text { RA (3) } \\
\text { AS (1) } \\
\text { EnterA (1) } \\
\text { Undiff (1) }\end{array}$ \\
\hline
\end{tabular}

AS, ankylosing spondylitis; ASD, adult Still's disease; EnterA: enteropathic arthritis; ERA, Enthesitis-Related Arthritis; jPsA : juvenile Psoriatic Arthritis; Persist/Extend Oligo, persistent/ extended oligoarticular JIA; PsA, psoriatic arthritis; RA, rheumatoid arthritis; RFneg Poly JIA, rheumatoid factor negative polyarticular JIA; RFpos Poly JIA, rheumatoid factor positive polyarticular JIA; Syst JIA, systemic JIA; USpA, undifferentiated spondyloarthritis; Undiff, undifferentiated arthritis.

hopefully help defining more relevant disease categories. In fact, a recent report from a large consortium on JIA genetics shows that the JIA categories potentially have adult counterparts: the strong associations between RF-positive polyarthritis and specific human leukocyte antigen (HLA) DRB1* alleles are seen both in children and adults. ${ }^{21}$ Interestingly, the combined oligoarthritis and RF-negative polyarthritis categories share the same HLA association with adult seronegative RA. ${ }^{21}$

So how are Oliveira-Ramos $e t$ al's results clinically relevant to the up-coming change in ILAR classification? For the caregiver, the nomenclature and classification guide treatment and follow-up strategies. For the patient, receiving the most effective treatment is the main objective. We know that JIA categories change over time in children and may also change in adults, when they are followed closely for features of psoriasis, enthesitis or spondyloarthropathy, or when adult rheumatologists rename the juvenile rheumatic disease. The work of Oliveira-Ramos $e t a l$ is of crucial importance in this time of redefining JIA classification. Further studies of genetic and early clinical characteristics of JIA in children, in order to collect RA, SpA or PsA specific traits, 
may be a way to unify the paediatric and adult classifications of rheumatic diseases, for the entire benefit of our children and adolescents. We hope our patients can finally recognise themselves as having the same disease from childhood to adulthood.

Acknowledgements We want to thank UiT The Arctic University of Norway for funding the publication charges for this editorial, and also thank Helse Nord RHF Research Program for funding.

Funding UiT The Arctic University of Norway and Helse Nord RHF Research Program

Competing interests None declared.

Provenance and peer review Not commissioned; externally peer reviewed.

Data sharing statement No additional data are available.

Open Access This is an Open Access article distributed in accordance with the Creative Commons Attribution Non Commercial (CC BY-NC 4.0) license, which permits others to distribute, remix, adapt, build upon this work noncommercially, and license their derivative works on different terms, provided the original work is properly cited and the use is non-commercial. See: http:// creativecommons.org/licenses/by-nc/4.0/

\section{REFERENCES}

1. McDonagh JE, Viner RM. Lost in transition? Between paediatric and adult services. BMJ 2006;332:435-6.

2. Martini $A$. It is time to rethink juvenile idiopathic arthritis classification and nomenclature. Ann Rheum Dis 2012;71:1437-9.

3. Petty RE, Southwood TR, Manners $P$, et al. International League of Associations for Rheumatology classification of juvenile idiopathic arthritis: second revision, Edmonton, 2001. J Rheumatol 2004:31:390-2.

4. Fantini F. Classification of chronic arthritides of childhood (juvenile idiopathic arthritis): criticisms and suggestions to improve the efficacy of the Santiago-Durban criteria. J Rheumatol 2001;28:456-9.

5. Hofer MF, Mouy R, Prieur AM. Juvenile idiopathic arthritides evaluated prospectively in a single center according to the Durban criteria. J Rheumatol 2001;28:1083-90.

6. Tsitsami E, Bozzola E, Magni-Manzoni S, et al. Positive family history of psoriasis does not affect the clinical expression and course of juvenile idiopathic arthritis patients with oligoarthritis. Arthritis Rheum 2003;49:488-93.

7. Merino R, de Inocencio J, García-Consuegra J. Evaluation of revised International League of Associations for Rheumatology classification criteria for juvenile idiopathic arthritis in Spanish children (Edmonton 2001). J Rheumatol 2005;32:559-61.

8. Martini A. Are the number of joints involved or the presence of psoriasis still useful tools to identify homogeneous disease entities in juvenile idiopathic arthritis? J Rheumatol 2003;30:1900-3.

9. Pagnini I, Savelli S, Matucci-Cerinic M, et al. Early predictors of juvenile sacroiliitis in enthesitis-related arthritis. J Rheumatol 2010;37:2395-401.

10. Burgos-Vargas R. The assessment of the spondyloarthritis international society concept and criteria for the classification of axia spondyloarthritis and peripheral spondyloarthritis: a critical appraisal for the pediatric rheumatologist. Pediatr Rheumatol Online $J$ 2012;10:14.

11. Stoll ML, Lio P, Sundel RP, et al. Comparison of Vancouver and International League of Associations for rheumatology classification criteria for juvenile psoriatic arthritis. Arthritis Rheum 2008; 59:51-8.

12. Ekelund M, Aalto K, Fasth $\mathrm{A}$, et al. Psoriasis and associated variables in classification. and outcome of juvenile idiopathic arthritis - an eight-year follow-up study. Pediatr Rheumatol Online J 2017 Feb 22;15:13.

13. Ferrell EG, Ponder LA, Minor LS, et al. Limitations in the classification of childhood-onset rheumatoid arthritis. J Rheumatol 2014;41:547-53.

14. Oliveira-Ramos F, Eusébio M, Martins F, et al. Juvenile idiopathic arthritis in adulthood: fulfilment of classification criteria for adult rheumatic diseases, long-term outcomes and predictors of inactive disease, functional status and damage. RMD Open 2016;2: e000304.

15. Nordal E, Zak M, Aalto K, et al. Ongoing disease activity and changing categories in a long-term Nordic cohort study of juvenile idiopathic arthritis. Arthritis Rheum 2011;63:2809-18.

16. Ravelli A, Felici E, Magni-Manzoni S, et al. Patients with antinuclear antibody-positive juvenile idiopathic arthritis constitute a homogeneous subgroup irrespective of the course of joint disease. Arthritis Rheum 2005;52:826-32.

17. Ravelli A, Varnier GC, Oliveira S, et al. Antinuclear antibody-positive patients should be grouped as a separate category in the classification of juvenile idiopathic arthritis. Arthritis Rheum 2011;63:267-75.

18. Nordal E, Songstad NT, Rygg M. Difficulties in defining antinuclear antibody-positive patients as a separate category in the classification of juvenile idiopathic arthritis: comment on the article by Ravelli et al. Arthritis Rheum 2011;63:2835; author reply 2835-6.

19. Tuttle KS, Vargas SO, Callahan MJ, et al. Enthesitis as a component of dactylitis in psoriatic juvenile idiopathic arthritis: histology of an established clinical entity. Pediatr Rheumatol Online J 2015;13:7.

20. Ritchlin CT, Krueger JG. New therapies for psoriasis and psoriatic arthritis. Curr Opin Rheumatol 2016;28:204-10.

21. Hinks A, Bowes J, Cobb J, et al. Fine-mapping the MHC locus in juvenile idiopathic arthritis (JIA) reveals genetic heterogeneity corresponding to distinct adult inflammatory arthritic diseases. Ann Rheum Dis 2016;76:765-72. 